\title{
СОцІОЛОГІя
}

УДК $316+314.3$

DOI https://doi.org/10.32837/apfs.v0i27.924

\author{
С. Ю. Аксьонова \\ ORCID ID: https://orcid.org/0000-0003-0516-9078 \\ кандидат економічних наук, \\ провідний науковий співробітник \\ Інституту демографії та соиіальних досліджень імені М. В. Птухи \\ Національної академії наук України

O. I. Василещь
ORCID ID: https://orcid.org/0000-0002-0753-3665
старший викладач кафедри соиіологї
Національного технічного університету України
«Київський політехнічний інститут імені Ігоря Сікорського»

\section{РЕПРОДУКТИВНА ПОВЕДІНКА В СУЧАСНОМУ УРБАНІЗОВАНОМУ СУСПІЛЬСТВІ}

Постановка проблеми. Вирішення питань оптимізації соціального розвитку нашого суспільства обов'язково виводить дослідників до вивчення демографічної складової частини соціальної поведінки особистостей, що пов'язано з несприятливою демографічною ситуацією в країні, зумовленою насамперед низькою народжуваністю, яка не забезпечує навіть рівень простого відтворення населення, коли кількість населення, хоча й не зростає, але й не знижується. Фактори зниження народжуваності постійно перебувають у дослідницькому полі демографів і соціологів. Необхідно визнати, що усі чинники дітородної активності тісно переплетені між собою, тому неможливо не лише чітко відокремити вплив одного фактору від іншого, але й виділити домінуючий чинник зниження народжуваності [1]. Дослідження ускладняються тим, що чимало факторів мають неоднозначний характер впливу або можуть змінювати вектор впливу на різних етапах суспільного розвитку.

Неодноразово було підтверджено, що розвиток міських поселень і поширення міського способу життя супроводжуються зниженням рівня народжуваності (особливо серед міського населення). Водночас існують приклади країн, що розвиваються, у яких у містах рівень народжуваності $є$ (чи був у певний історичний період) вищим, ніж у сільській місцевості; крім того, кореляції між тенденціями урбанізації та народжуваності не одразу зрозумілі, коли дослідження охоплюе широке коло країн [2]. Якщо розглянути регіони України, то можна побачити, що ситуація також не є однозначною. Зокрема, найнижчою питомою вагою міського населення у загальній чисельності регіону характеризується Закарпатська область, і той факт, що цій області притаманний порівняно з іншими регіонами країни високий рівень народжуваності, є цілком логічним, водночас різниця між показниками сумарної народжуваності міського й сільського населення області є зовсім неістотною (найменшою серед областей України). Іншим прикладом є Тернопільська область. Питома вага міського населення у чисельності всього населення області є значно нижчою за середній показник по Україні (44,9\% і $69,3 \%$ відповідно), водночас сумарний показник народжуваності в області теж є одним із найнижчих у країні, тобто наявна невідповідність зазначеному раніше взаємозв'язку рівня урбанізації та народжуваності. Подібна ситуація наявна у Черкаській області. Як виняток також можна розглядати урбанізовану Одеську область, де рівень дітородної активності суттєво перевищує середній по країні рівень (1,45\%о проти $1,30 \%$ ). У Сумській області частка міського населення є значно нижчою, ніж у Харківській області, а рівні народжуваності майже однакові.

Отже, за безсумнівності зниження народжуваності під впливом урбанізації у глобальному контексті, зв'язок цих процесів за доволі високого рівня урбанізації або у конкретних умовах суспільного розвитку потребує подальших досліджень. Ще важливіше дізнатися, як змінюються характеристики репродуктивної поведінки в сучасних урбанізованих суспільствах, які наслідки матимуть ці зміни у контексті соціального розвитку, адже постійна модернізація соціально-економічних умов людської життєдіяльності, експотенційний технологічний розвиток формують простір суспільних практик саме у форматі мегаполісів. Це особливо актуально для країн периферії

(ㄷ) С. Ю. Аксьонова, О. І. Василець, 2020 
(до якої нині належить Україна) та напівпериферії, якщо послуговуватися положеннями світ-системної теорії I. Валлерстайна [3].

Аналіз попередніх досліджень. Оскільки процес урбанізації охоплює - безпосередньо чи опосередковано - майже усі сфери життєдіяльності суспільства, інтерес до його вивчення виявляли науковці різних спеціальностей. Запит на з'ясування впливу урбанізації на психологію людини, її діяльність і поведінку не є новим, адже ще у середині минулого століття як напрям соціальної психології та філософії, що вивчає психологічний вплив міського середовища, виникла психогеографія. Французький філософ, письменник і громадський діяч Гі Дебор сприймав місто як місце безперервного протистояння і боротьби. У сучасних умовах Річард Флорида позначає саме місто як локацію життя креативного класу [4].

Вчені Бразильського інституту географії та статистики, досліджуючи зв'язки урбанізації та народжуваності, знайшли підтвердження того, що процес урбанізації не лише здійснює прямий вплив на дітородну поведінку, але й діє через зміни основних соціально-економічних детермінант [2]. У роботі також представлено огляд концепцій і теоретичних підходів до зв'язків урбанізації, міграції та народжуваності: від тих, що з'явилися у 19301940-х рр. минулого століття, до найновітніших.

О. Долінченко і Н. Кризина проаналізували найбільш важливі тенденції урбанізації, що формуються у новому тисячолітті, а також проблеми великих міст Європи і відображення цих проблем у демографічній політиці європейських країн [5], що може впливати на дітородні установки і поведінку.

Колектив науковців м. Дніпро на прикладі рідного міста проаналізував комплекс його соціальних та культурних сучасних проблем, розробив теоретико-методологічні засади дослідження особистості та соціальних інститутів в урбанізованому суспільстві, розглянув систему цінностей городян, гендерні питання й проблеми якості освіти [6].

Мета представленого дослідження полягає у з'ясуванні новітніх особливостей змін дітородних орієнтацій і поведінки під впливом урбанізаційних процесів як системного явища.

Виклад основного матеріалу дослідження. Причинно-наслідкові зв'язки урбанізації, як i будь-якого тривалого у часі явища, можуть змінюватися на різних етапах розвитку суспільства. Безперечним залишається створення у великих містах «урбаністичних зразків, що копіюються й унаслідуються іншими поселеннями», а також ïх вплив «через здійснення ними управлінських та інноваційних функцій» [7]. Дослідження формування урбаністичних зразків і механізмів їх копіювання та освоєння іншими поселеннями є важливими не лише для з'ясування особливостей ситуації сьогодення, але й для прогнозування перебігу багатьох процесів у майбутньому. Зокрема, зміни репродуктивної поведінки, які розгортаються у великих містах, поступово охоплюють інші поселення.

Вибіркові соціологічні обстеження виявили, що «локальна та регіональна ідентичності української молоді є сильнішими за національну: 73\% опитаних повною мірою бачать себе як мешканці свого міста, 69\% - як жителі свого регіону й лише $66 \%$ - як громадяни України» [8, с. 19]. У зв'язку з цим логічно припустити, що характер репродуктивних орієнтацій та загалом поведінки міських мешканців може визначатися не лише соціально-економічними факторами, але й уявленнями про належну для городян дітородну поведінку, наприклад переконанням, що в умовах великого міста дітей у сім’ї може бути щонайбільше двоє (хоча, скажімо, рівень матеріального забезпечення дає змогу утримувати і виховувати щонайменше трьох або навіть більше дітей). Принагідно зауважимо, що в Україні сім'я з двома дітьми залишається найбажанішим варіантом: майже половина респондентів віком 14-29 років заявила, що планує або хотіла б мати двох дітей. Водночас 4\% респондентів повідомили, що не хотіли б мати жодної дитини [8, с. 102]. Необхідно зазначити, що нині в Україні не спостерігається вагомої різниці у репродуктивних настроях міської та сільської молоді [9, с. 18], хоча дані вибіркових обстежень умов життя домогосподарств України свідчать про те, що частка домогосподарств, у складі яких є троє та більше дітей, серед усіх домогосподарств 3 дітьми в сільській місцевості перевищує ту, що у міських поселеннях (у 2019 р. показники становили 5,2\% і 1,7\% відповідно, а у великих містах - 1,4\% ) [10, с. 13].

Трансформація і трансляція дітородних установок масштабніше спостерігаються у метрополісах, які виокремлюються міжнародним статусом, з локалізацією господарських та суспільних функцій, ключових з точки зору світового господарства [7]. В метрополісах репродуктивні орієнтації «виходять» за межі норм, прийнятих суспільством у країні їх розташування. Оскільки доволі часто приймаються зразки поведінки (стереотипи, уявлення) тих груп, членом яких індивід не є, але до яких прагне належати, найімовірніше, що зразками репродуктивної поведінки мешканців метрополісів будуть установки й норми, що наявні у розвинутих світових містах, з якими налагоджені найпотужніші канали взаємодії.

У великих містах і метрополісах чітко проявляються протистояння, боротьба, конкуренція, що мають неабияке значення під час реалізації намірів щодо бажаного числа дітей у сім’ї. Ще у 1930-х pp. англійський демограф А. Карр-Саундерс показав, що ступінь конкуренції здатен сильніше за добробут впливати на рівень народжува- 
ності у суспільстві, адже люди, захищені своєю професією або іншими обставинами від конкуренції, схильні народжувати більше дітей, ніж ті, хто не має такого захисту. Розвиваючи ці думки Ю. Кузовков дійшов висновку, що не всі види конкуренції, а лише несправедлива конкуренція є значущим чинником для народжуваності [11]. Показниками несправедливої конкуренції є дискримінація, масова імміграція (коли відбувається витіснення праці місцевих працівників дешевшою працею менш вимогливих іммігрантів), високий рівень безробіття, за яких конкуренція між найманими працівниками стає гострішою. Проблема несправедливої конкуренції порушує питання нерівності, однак, на думку В. Галецького, для суспільства реальною небезпекою є не стільки нерівномірність розподілу соціально-економічних благ, скільки те, що ці блага розподілені занадто нерівномірно, а природна соціально-економічна нерівність виходить за допустимі межі [12]. Соціально-економічна нерівність зростає швидше у містах та агломераціях, які більші за розміром, мають більшу густоту населення.

Концентрація економічного, соціального, культурного, інноваційного, інформаційного капіталів у великих містах розширює можливості для самореалізації особистості у позасімейних сферах. Зокрема, концентрація різних видів діяльності уможливлює i прискорює професійну реалізацію, кар'єрне зростання, і в цьому випадку вплив урбанізації переходить у площину впливу можливостей професійного розвитку (і зайнятості загалом) на репродуктивну поведінку.

В умовах урбаністичної концентрації інтенсифікуються майже всі напрями життєдіяльності, прискорюється суспільний розвиток, що немалою мірою зумовлює зміни пріоритетів в ієрархії цінностей сучасних суспільств. Більш того, ці зміни загалом можуть бути передбачуваними, оскільки тісно вони пов'язані із соціально-економічним розвитком. Зміни у системі цінностей не лише зумовлюють перегляд релігійних переконань, трудової мотивації, гендерних ролей, але й впливають на сексуальні норми та рівень народжуваності [13]. Численні соціологічні опитування показують, що порівняно зі старшим поколінням молодь більшою мірою поділяє цінності досягнення, орієнтована на самореалізацію, дотримується власних переконань і відстоює їх. Найбільше тяжіє до цінностей самовираження молодь великих міст.

Зміни охопили й систему сімейних цінностей. Якщо у традиційній культурі здебільшого осуджуються ті види поведінки, що перешкоджають дітонародженню і вихованню дітей у сім’ї, то у постіндустріальному суспільстві інститути соціального забезпечення, як правило, високорозвинені, тому загальноприйняті норми слабішають, поширюється толерантне ставлення до багатьох неприпустимих раніше явищ. Зокрема, змінюється ставлення до феномена добровільної бездітності, або чайлдфрі. Ф. Тьонніс зазначав, що у великих містах справжню впливовість і життєздатність мають тільки могутні, багаті, освічені люди, які задають ту міру, якою повинні керуватися інші і у своєму прагненні потіснити їх, і у своєму намаганні їм уподібнитися [14]. Інтерв'ю, які все частіше й частіше з'являються у засобах масової інформації, коментарі та повідомлення, розміщені на форумах, де активно обговорюються теми добровільної бездітності, свідчать про те, що доволі часто представниками чайлдфрі є успішні підприємці, ті, хто багато часу приділяють роботі, кар’єрі. Зацікавленість у роботі сприяє успішному виконанню професійних функцій та особистісній самореалізації, що позитивно позначається на доходах, соціальному статусі, отже, на умовах життєдіяльності. Як правило, ті, хто не планують народжувати і виховувати дітей, більше затребувані як професіонали, i роботодавці за рівних інших умов більше схильні надати ним перевагу під час працевлаштування, а також віддати керівну посаду, адже такі працівники не будуть відволікатися від роботи через необхідність доглядати за дитиною/дітьми (особливо у період хвороби у дитини), присвячувати певний час виконанню батьківських обов'язків, матимуть можливість у будь-який час поїхати у відрядження, залишатися на роботі стільки, скільки необхідно для вирішення складної проблеми. Отже, фінансова незалежність, свобода вибору, висока конкурентоздатність і затребуваність на ринку праці, великі можливості для самореалізації посилюють привабливість представників добровільної бездітності, і вони «задають ту міру» (за Ф. Тьоннісом), якою будуть прагнути керуватися молоді люди, які ще не визначилися 3 пріоритетами у житті та дітородні орієнтації яких ще повністю несформовані. На жаль, неможливо навести точні статистичні дані щодо кількості чайлдфрі-адептів (це проблема не лише для України) та оцінити швидкість поширення цього феномена, але є підстави вважати, що у великих містах ідеї чайлдфрі поширюватимуться швидше та охоплюватимуть різні соціальні групи молоді.

Результати соціально-демографічного обстеження населення дітородного віку «Сім'я і сімейні відносини» показали, що обмеження кількості дітей у сім'̈і є тим більшим, чим сильніше бажання досягти успіхів у кар'єрі, а зайнятість і професійне навантаження, через які респондент не має достатньо часу для догляду і виховання дітей, сприймалися як перепона для народження бажаної кількості дітей здебільшого респондентами, які навіть за наявності необхідних умов хотіли б мати лише одну дитину [15, с. 142-143].

На нашу думку, роль засобів масової інформації у змінах репродуктивної поведінки 
здебільшого недооцінюється. Однак саме вони транслюють цінності (зокрема, ті, що впливають на прийняття рішень щодо дітонародження) у найзручнішій для наслідування формі, саме вони обумовлюють формування певної ієрархії в особистісній системі цінностей, спричиняють або прискорюють зміни, саме вони мають найбільшу аудиторію, адже в урбанізованих суспільствах перегляд телевізійних передач являє собою другу найбільшу категорію діяльності після роботи [16, с. 320].

У великих містах створюються умови для підвищення соціального статусу, більш комфортного життя, полегшення догляду за дітьми та їх виховання, повнішого розвитку особистісного потенціалу та здібностей дитини завдяки можливостям навчатися у хорошому освітньому закладі (школі, гімназії, ліцеї), відвідувати різноманітні гуртки, секції, центри або спеціалізовані школи (спортивні, художні тощо) чи просто завдяки «символічній участі в престижному споживанні, включаючи мистецтво і розваги» [16, с. 362]. Водночас урбанізоване суспільство вимагає від батьків бути відповідальними щодо піклування і виховання дитини, добре інформованими про шляхи її гармонійного розвитку. Сьогодні турбота за дитиною виходить далеко за межі простого забезпечення харчуванням, одягом, гігієною. Важливо бути обізнаними щодо різних методів виховання, орієнтуватися на ринку соціальних послуг по догляду, вихованню i розвитку дітей, особливо в тому його сегменті, котрий представлений агенціями, приватними особами, які задовольняють попит на послуги щодо індивідуального догляду чи освітньо-виховної роботі з дітьми дошкільного віку. Загалом відбувається зміщення пріоритетів із кількісних аспектів відтворення населення на якісні.

Збільшення можливостей для підвищення освітнього рівня, професійного зростання, самореалізації, поліпшення добробуту в урбанізованих осередках немалою мірою посилює намір відкладати дітонародження на старший вік (це характерно як для жінок, так і для чоловіків), щоб мати змогу спочатку досягти належного рівня матеріального благополуччя, соціального статусу, створити необхідні умови для народження дитини і виконання батьківських функцій. Тенденція відкладання народження дитини на старший вік також зародилась у великих містах і поступово поширюється на інші поселення, зокрема сільську місцевість. Так, у новому тисячолітті в Україні материнській вік як у міських поселеннях, так і у сільській місцевості підвищився, але у містах він зріс на 3,1 роки, а в селах - на 2,3 роки (середній вік матері під час народження дитини у 2018 р. у міських поселеннях становив 28,4 років, у сільській місцевості 26,7 років). В урбанізованому суспільстві швидше опановують нові тенденції (збільшення віку матері під час народження дитини є новітньою тенденці- єю в демографічній історії України, оскільки вона розпочалась у другій половині 1990-х рр.). Спостерігається певна залежність швидкості змін від розмірів поселень. Наприклад, у США протягом 20072017 рр. середній вік матері під час народження первістка у сільських поселеннях зріс на 1,3 року, у невеликих або середніх - на 1,5 року, а у великих на 1,8 року [17]. Принагідно зазначимо, що підвищення віку материнства в Україні відбувається в унісон тенденціям, характерним для усіх розвинутих країн світу, хоча дещо повільніше. Як правило, в Україні більш урбанізовані області мають більші показники віку материнства з найвищим його значенням у м. Київ (30,3 роки для усіх черговостей народження). Напружений ритм життя столичного міста спонукає його мешканців відкладати початок дітородної діяльності на старший вік. Якщо загалом середній вік матері під час народження первістка в Україні був на рівні 25,4 роки, то в Києві він становив 28,7 років, а от у найменш урбанізованій Закарпатській області спостерігається найнижчий показник, а саме 23,3 роки.

У великих містах уможливлюється вирішення проблем з безпліддям через застосування допоміжних репродуктивних технологій та їх більшої доступності для населення, удосконалення діагностики захворювань у пренатальний період, довіру до медичних інновацій, що підтверджується зростанням кількості звернень щодо допоміжних репродуктивних технологій (ДРТ).

Висновки. Розвиток міських поселень і поширення міського способу життя зазвичай супроводжуються зниженням рівня народжуваності у країні. Особливості дітородної поведінки у сучасному урбанізованому суспільстві проявляються як обмеження числа дітей у сім'ї, зміщення дітонароджень на старший вік матері/батька, посилення чайлдфрі-настроїв серед молоді, зосередження на якісних аспектах відтворення населення. Така поведінка розширює можливості для успішної особистісної реалізації (професійної, соціальної тощо), сприяє зростанню конкурентоздатності, що підвищує рівень добробуту i сприяє накопиченню людського капіталу, але водночас посилює деформаційні процеси у відтворенні населення. В урбанізованому суспільстві, з одного боку, створюються необхідні умови для народження дітей і піклування про них, а з іншого боку, підвищуються вимоги до батьків, посилюється критичне ставлення до їх відповідальності за утримання і виховання дітей.

\section{Jimepamypa}

1. Миронин С., Козырева О. Причины второго демографического перехода. Золотой лев. 1999. № 63-64. URL: http: //www.zlev.ru/65_36.Htm.

2. Martine G. Eustaquio Alves J., Cavenaghi S. Urbanization and Fertility Decline: Cashing in 
on Structural Change. International Institute for Environment and Development. 2013. URL: www.jstor. org/stable/resrep01293.

3. Валлерстайн И. Анализ мировых систем и ситуация в современном мире / пер с англ. П. Кудюкина, под ред. Б. Кагарлицкого. Санкт-Петербург : Университетская книга, 2001. 416 с.

4. Florida R. Cities and the Creative Class. Routledge, 2005 URL: https://creativeclass.com/rfcgdb/ articles $/ 4 \%$ 20Cities $\% 20$ and $\% 20$ the $\%$ 20Creative $\% 20$ Class.pdf.

5. Долінченко О., Кризина Н. Досвід європейських країн щодо державного регулювання демографічних процесів у великих містах. Державне управління: удосконалення та розвиток. 2014. № 3. URL: http://nbuv.gov.ua/UJRN/Duur_2014_3_9.

6. Особистість і соціальні інститути в урбанізованому суспільстві: місто Дніпро : монографія : у 2 т. / за заг. ред. В. Кривошеїна. Т. 1. Дніпро, 2018. 289 с. URL: dnu.dp.ua/docs/facults/fsocgum/sociologia.

7. Мазур Т., Король Є. Еволюція змісту термінів «метрополізація», «метрополія», «метрополійний ареал», «метрополійний простір» в контексті урбанізаційних процесів XX - початку XXI століть. Bicник Національного університету «Львівська політехніка». 2010. №675: Проблеми української термінології. C. 28-33.

8. Українське покоління Z: цінності та орієнтири. Результати загальнонаціонального опитування, 2017. 137 c. URL: http://neweurope.org.ua/analytics/ ukrayinske-pokolinnya-z-tsinnosti-ta-oriyentyry.

9. Цінності української молоді. Результати репрезентативного соціологічного дослідження становища молоді, 2016. 91 с. URL: https://www.prostir.ua/ ?library=tsinnosti-ukrajinskoji-molodi.

10. Соціально-демографічні характеристики домогосподарств України у 2019 році (за даними вибіркового обстеження умов життя домогосподарств) : статистичний збірник. Київ : Державна служба статистики України. URL: http://www.ukrstat.gov.ua/druk/ publicat/kat_u/2019/zb/07/zb_sdhdu2019.pdf.

11. Кузовков Ю. Демограффическая концепция в трилогии «Неизвестная история». URL: http://www. yuri-kuzovkov.ru/theory/demographich.

12.Галецкий В. Демографическая глобализация: проблемы. Дружба Народов. 2004. № 11. URL: http://magazines.russ.ru/druzhba/2004/11/ga8.html.

13.Инглхарт Р., Вельцель К. Модернизация, культурные изменения и демократия: Последовательность человеческого развития Москва : Новое издательство, 2011. 464 с. URL: https://www.hse.ru data 2012/02/24 inglehart_welzel.

14. Теннис Ф. Общность и общество. Основные понятия чистой социологии. Санкт-Петербург : Владимир Даль, 2002. 400 с.

15. Сім'я та сімейні відносини в Україні: сучасний стан і тенденції розвитку. Київ : ТОВ «Основа-Принт», 2009. 248 c.

16. Кастельс М. Информационная эпоха: экономика, общество и культура / пер. с англ., под науч. ред. О. Шкаратана. Москва : ГУ ВШЭ, 2000. 608 с.

17. Ely D.M. and Hamilton B. E. Trends in Fertility and Mother's Age at First Birth Among Rural and
Metropolitan Counties. United States, 2007-2017. URL: https://www.cdc.gov/nchs/data/databriefs/db323-h.pdf.

\section{Анотація}

Аксьонова С. Ю., Василець О. І. Репродуктивна поведінка в сучасному урбанізованому суспільстві. Стаття.

Процес урбанізації є багатовимірним і охоплює різноманітні сфери життєдіяльності, зокрема дітородну активність. Аналіз причин зниження народжуваності під впливом урбанізації є особливо актуальним і з огляду на глобальні контексти цього явища, і з урахуванням необхідності розвитку вітчизняної економіки, зокрема її втрат внаслідок пандемії. У статті показано, як доволі сильна локальна ідентичність української молоді може обумовлювати формування або зміну репродуктивних установок відповідно до уявлень про належну поведінку для жителів великих міст, метрополісів.

3'ясовано, що урбанізація завдяки концентрації економічного, соціального, культурного, інноваційного, інформаційного капіталів прискорює суспільний розвиток, а це разом з іншими чинниками зумовлює зміни у системі цінностей молоді. У статті зазначається, що прагнення самореалізації (насамперед, у професійній, соціальній сфері), як правило, створює необхідність відкладати народження дитини на старший вік; крім цього, в умовах поширення толерантного ставлення суспільства до різноманітних способів життя, зокрема бездітного, також формується відмова від народження дитини взагалі. Отже, загалом позитивна тенденція зміщення пріоритетів із кількісних аспектів відтворення населення на якісні водночас поглиблює і підсилює ризики самих процесів відтворення. Наголошується на значущості 3МІ у проведенні ідей відповідального батьківства як складової частини оптимізації репродуктивної поведінки людей в урбанізованому соціальному просторі сьогодення.

Оскільки соціальна спроможність держави грунтується на конструктивному ставленні до людського капіталу, то громадяни країни становлять найцінніший ресурс розбудови демократичного простору у нашій Батьківщині.

Отже, у статті доводиться, що репродуктивна поведінка як один із головних чинників формування демографічної мапи суспільства має досліджуватися синергетичними зусиллями представників поведінкових, соціальних, гуманітарних наук, адже старіння населення є комплексним викликом для України. Це стосується не тільки вимог ринку праці, але й можливості держави виконувати соціальні зобов'язання перед своїми громадянами різного віку.

У статті підкреслюється, що конкурентні стосунки, загострюючись у метрополісах, негативно впливають на відтворення населення у буквальному розумінні, тому звертається увага на те, що прагнення до самореалізації під час здійснення останньої через гедоністичну модель поведінки призводить до втрати перспективного бачення наслідків власного вибору і стоїть на перешкоді прогресивному розвитку і країни, і особистості.

Ключові слова: урбанізація, суспільство, репродуктивна поведінка, народжуваність. 


\section{Summary}

Aksyonova S. Yu., Vasilec O. I. Reproductive behavior in the modern urban society. - Article.

The process of urbanization is multidimensional and covers various spheres of life, including reproductive activity. Analysis of the causes of declining birth rates under the influence of urbanization is particularly relevant given the global contexts of this phenomenon, and given the need for development of the domestic economy, its losses due to the pandemic, in particular. The article shows how a fairly strong local identity of Ukrainian youth can lead to the formation or change of reproductive attitudes in accordance with the notions of proper behavior for residents of large cities and metropolises.

It was found that urbanization, due to the concentration of economic, social, cultural, and innovative, information capital accelerates social development, and this, in turn, along with other factors, causes changes in the value system of youth. The article notes that the desire for selfrealization (especially in the professional, social sphere), as a rule, creates the need to postpone the birth of a child to an older age; in addition, with the spread of a tolerant attitude of society to various lifestyles, including childless, it may also lead to the refusal of the birth of a child at all. Therefore, it is concluded that in general the positive trend of shifting priorities from quantitative aspects of population reproduction to qualitative ones, at the same time deepens and strengthens the risks of the reproduction processes themselves. The importance of the media in carrying out the ideas of responsible parenthood as a component of optimizing the reproductive behavior of people in the urban social space of today is emphasized.

Since the social capacity of the state is based on a constructive attitude to human capital, accordingly, the citizens of the country are the most valuable resource for building a democratic space in our country. Based on this, the article argues that reproductive behavior as one of the main factors in shaping the demographic map of society must be studied by synergistic efforts of behavioral, social, humanities, because population aging is a complex challenge for Ukraine. This applies not only to the requirements of the labor market, but also to the ability of the state to fulfill social obligations to its citizens of all ages. The article emphasizes that competitive relations, intensifying in metropolises, negatively affect the reproduction of the population in the literal sense. Therefore, the article draws attention to the fact that the desire for self-realization, in the implementation of the latter through a hedonistic model of behavior, leads to a loss of perspective vision of the consequences of their own choice and hinders the progressive development of both country and individual.

Key words: urbanization, society, reproductive behavior, fertility. 